Review

\title{
The Roles of Collagen in Islet Transplantation
}

Naoaki Sakata ${ }^{1,2, *}$, Gumpei Yoshimatsu ${ }^{1,2}$, Shohta Koadama ${ }^{1,2}$

1. Department of Regenerative Medicine and Transplantation, Faculty of Medicine, Fukuoka University, 7-45-1 Nanakuma, Jonan, Fukuoka 814-0180, Japan; E-Mails: naoakisakata@fukuokau.ac.jp; gyoshimatsu@fukuoka-u.ac.jp; skodama@fukuoka-u.ac.jp

2. Center for Regenerative Medicine, Fukuoka University Hospital, 7-45-1 Nanakuma, Jonan, Fukuoka 814-0180, Japan

* Correspondence: Naoaki Sakata; E-Mail: naoakisakata@fukuoka-u.ac.jp

Academic Editors: Kenneth L. Brayman and Preeti Chhabra

Special Issue: Islet Cell Transplantation

OBM Transplantation

2020, volume 4, issue 4

doi:10.21926/obm.transplant.2004127
Received: October 02, 2020

Accepted: November 15, 2020

Published: November 27, 2020

\begin{abstract}
Islet transplantation is a cellular replacement therapy for severe diabetes mellitus. Although the clinical outcome of islet transplant has been improving, the transplant efficacy of this treatment is not superior to that of pancreatic organ transplantation, a similar transplant therapy. Various factors have been characterized as 'islet transplantation specific', which includes lack of revascularization and ischemia, innate inflammation, or autoimmunity, affect the therapeutic outcome of this treatment. Among them, the impairment of islets by digestion of extracellular matrix (ECM) via the islet isolation and transplantation process is one of the major factors to avoid islet engraftment. The islet is composed of endocrine cells aggregated by ECMs. Particularly, collagen is a target for the digestion of the pancreas for islet isolation. Furthermore, collagen improves endocrine functions, survival, and proliferation. In this study, we review the importance of collagen in islet transplantation.
\end{abstract}

\section{Keywords}

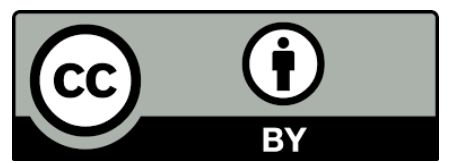

(C) 2020 by the author. This is an open access article distributed under the conditions of the Creative Commons by Attribution License, which permits unrestricted use, distribution, and reproduction in any medium or format, provided the original work is correctly cited. 
$\beta$ Cells; collagen; collagenase; extracellular matrix; insulin; islet; islet isolation; islet transplantation

\section{Introduction}

Islet transplantation is a cellular replacement therapy for severe diabetes mellitus (DM), including brittle type $1 \mathrm{DM}$, that stabilizes blood glucose control with appropriate insulin supplies. The clinical outcome of this treatment is improved significantly because of innovations in pancreas procurement, islet isolation, methods of transplantation, and regimen of immunosuppressive agents [1]. Recently, two phase 3 clinical trials of islet transplantation for type 1 DM were reported. The first clinical trial purified human pancreatic islets in patients with type 1 DM after kidney transplant (CIT-06), which indicated that $62.5 \%$ of patients achieved the primary endpoint of evading severe hypoglycemic events and between $1 \%$ and $6.5 \%$ reduction of $\mathrm{HbA1c}$ level at 1 year after islet transplantation. The median hemoglobin $\mathrm{A} 1 \mathrm{c}(\mathrm{HbA} 1 \mathrm{c})$ level was ameliorated at 1 year compared with before transplant $(6.0 \%$ vs. $8.1 \%)$. Furthermore, this protocol preserved the kidney allograft function for three years after islet transplantation [2]. The second clinical trial transplanted allogeneic pancreatic islet in type $1 \mathrm{DM}$ patients complicated by severe hypoglycemia with normal renal function (CIT-07). This study demonstrated that $87.5 \%$ and $71 \%$ of patients achieved an $\mathrm{HbA} 1 \mathrm{c}$ of $7.0 \%$ or less and prevented severe hypoglycemic events at 1 and 2 years, respectively, after the first transplantation [3]. To date, islet transplantation has been widely recognized as one of the standard therapies for type 1 DM worldwide.

In contrast, the transplant efficacy of islet transplantation is not superior to that of pancreas organ transplantation, a similar transplant therapy. Pancreas organ transplantation is a major surgery that is characterized by arterial/venous reconstruction into the right external iliac artery/vein with pancreatic drainage route using the bladder or ileum [4]. The pancreatic organ transplantation gives good therapeutic outcomes. Indeed, the graft survival rates (i.e., insulin independent rate) are almost $85 \%$ at one year and $>60 \%$ at five years [5], while insulin independent rate at five years was $39 \%$ in islet transplantation [6]. The transplantation of the pancreas can be safely performed. However, this procedure is more invasive compared to islet transplantation, which is an outpatient procedure. An annual report by the Collaborative Islet Transplant Registry indicated that transplantation of a higher volume of islets $(>10,450$ islet equivalents per body weight [kg]) results in successful prevention of severe hypoglycemic events in more than $80 \%$ of the recipients and restoration of the $\mathrm{HbA1c}$ level in more than $60 \%$ in both islet alone and islet after kidney transplantation for 5 years after transplantation (http://www.citregistry.org/). This means several (generally $>2$ ) islet transplantations are often needed, whereas only one transplantation enables the achievement of good endocrine function in pancreas transplantation. There are various factors, including lack of revascularization and ischemia [7, 8], innate inflammation [9], or autoimmunity [10], that affect the transplant outcome of islet transplantation. Among these factors, the impairment of the extracellular matrix (ECM) in the islet is a major reason for the prevention of islet engraftment. ECM is an extracellular component that plays a role as a scaffold that contributes to the formation of tissues and organs. Conversely, ECM regulates cell-to-cell interactions via the activation of various growth factors and cytokines [11]. The islet is composed of endocrine cells 
aggregated by ECM, like other tissues and organs. The breakdown of islet ECM by an enzyme is essential for the isolation of pancreatic islets from the donor pancreas. However, this leads to the destruction of islets and, as a consequence, may reduce islet dysfunction and survival.

ECM in islets comprises two macromolecules: glycosaminoglycans and fibrous proteins [11, 12]. Glycosaminoglycans are long, linear polysaccharides with a high molecular weight composed of repeating disaccharide units. Sulfated glycosaminoglycans are attached to a core protein at specific sites and form a compound known as proteoglycan. Proteoglycans are located in the interstitial tissues or the cellular membrane and provide hydrophilic conditions and interaction between the ligand and receptor via signaling molecules. There are several subtypes of glycosaminoglycans, including heparan sulfate, chondroitin sulfate, dermatan sulfate, and keratan sulfate [13]. Conversely, fibrous proteins, including collagen, elastin, fibronectin, and laminin, provide structural and functional benefits to cells, including islets [11]. Among them, we focus on collagen because it is not only a representative component of ECM but also its characteristics may affect the therapeutic outcome of islet transplantation. In this study, we review the importance of collagen in islet transplantation.

\section{Importance of Collagen in Islet Transplantation}

\subsection{Overview}

Collagen occupies approximately $30 \%$ of proteins in the human body $[11,14]$. The peptide chain of collagen comprises three repeating peptide triplets of glycine, amino acid $\mathrm{X}$, and amino acid $\mathrm{Y}$. Proline and hydroxyproline are often positioned in $X$ and $Y$, respectively. The three peptide chains, known as $\alpha$ chains, helically combine, and form collagen [14]. Presently, 28 different types of collagen are known and numbered from I to XXVIII [14]. Among them, collagens I, II, III, IV, and V have been identified as common in the human body [15]. Collagen I is the most abundant collagen and is a major component of the skin (>90\% of the mass), tendon, muscle, and bone $[16,17]$. Collagen II is a major component of cartilage [18], collagen III is a major component of reticular fiber and commonly coexists with collagen I $[11,17]$, and collagen $V$ has primarily been detected in the cellular surface, hair, and placenta [11]. Although collagens I, II, III, V, and XI are classified as fibrillar collagen or fibril-forming collagen [17], collagen IV is categorized as non-fibrillar collagen. This is the most pivotal structural component of the basement membrane $[11,17]$. Collagen VI is also classified as non-fibrillar collagen and comprises three different $\alpha$ chains [17]. There are two main reasons why collagen is important in islet transplantation, namely, as a target of pancreatic digestion for islet isolation and as a supporter of the endocrine function of islets.

\subsection{The Role of Collagen in Islet Transplantation: Target of Pancreatic Digestion for Islet Isolation}

As previously mentioned, collagen is a major target of enzymatic digestion for islet isolation. It is critical to digest collagen of peri-islet effectively and not to damage islets by digestion of intra-islet collagen, leading to the acquisition of a large volume of islets with keeping original endocrine function from the donor pancreas [19]. Therefore, understanding the distribution of collagen in the pancreas is necessary. Some groups have previously elucidated that the regulation of collagenase blend might affect the acquired volume of islets in islet isolation [20,21]. 
Table 1 shows the distribution of collagen in the pancreas and islets. The distribution varies according to the species. In pigs, collagens I, III, and IV are expressed in peri-islet, and the expression level is higher in older pigs than that in younger pigs [22]. Hughes et al. revealed that collagen VI was abundant in the interlobular and intralobular of acinar cells, compared with collagens I, IV, and $\mathrm{V}$ in juvenile and adult pigs. Furthermore, collagens I and VI are prominently detected in peri-islet, especially collagen VI [23]. Similar results were reported by Van Deijnen et al., who showed that collagen I was weakly expressed in peri-islet and in the lobar, lobular, and acinar septa and that collagen $\mathrm{V}$ also reacted weakly in the lobar and lobular septa [24]. Similar findings were also shown by Vigier et al., who found that the expression of collagen in pig pancreas was weaker in IV and V than in I, III, and VI [25]. Conversely, Goto et al. revealed the importance of collagen V digestion using collagenase $\mathrm{G}$ (collagenase I) for the success of porcine islet transplantation [26].

Table 1 Distribution of collagen in the pancreas and islet.

\begin{tabular}{|c|c|c|c|}
\hline Type of collagen & $\begin{array}{l}\text { Author (year), } \\
\text { Reference }\end{array}$ & Specimen & Detailed results \\
\hline I, II, III, IV, V & $\begin{array}{c}\text { Meier } \\
\text { (2020), [27] }\end{array}$ & Human & $\begin{array}{l}\text { Evaluated the correlation between the degree of } \\
\text { collagen digestion and acquired human islets } \\
\text { volume }\end{array}$ \\
\hline $\mathrm{I}, \mathrm{IV}, \mathrm{VI}$ & $\begin{array}{l}\text { Spiers } \\
\text { (2019), [28] }\end{array}$ & Human & $\begin{array}{l}\text { Evaluated the profiles of ECMs in human } \\
\text { pancreatic tissue for developing the donor-specific } \\
\text { collagenase }\end{array}$ \\
\hline IV & $\begin{array}{c}\text { Spiers } \\
\text { (2018), [29] }\end{array}$ & Human & $\begin{array}{l}\text { Assessment of collagenase for digestion of } \\
\text { collagen IV and laminin in the human pancreas }\end{array}$ \\
\hline IV & $\begin{array}{c}\text { Cross } \\
(2017),[30]\end{array}$ & Human & $\begin{array}{l}\text { Collagen IV and laminin presented in peri-islet in } \\
\text { humans }\end{array}$ \\
\hline $\mathrm{VI}$ & $\begin{array}{l}\text { Cross } \\
(2006),[19]\end{array}$ & Human & $\begin{array}{l}\text { Collagenase penetrates the islet by the current } \\
\text { techniques and led to low islet yields }\end{array}$ \\
\hline VI, I, IV, V & $\begin{array}{l}\text { Hughes } \\
(2006),[31]\end{array}$ & Human & $\begin{array}{l}\text { Collagens IV, V, and VI were present throughout } \\
\text { the human islet-exocrine interface, whereas } \\
\text { collagen I was seen at more variable sites } \\
\text { The mean peri-islet collagen VI proportion was } \\
\text { significantly greater than that of collagen I or IV }\end{array}$ \\
\hline XVIII & $\begin{array}{c}\text { Choong } \\
\text { (2015), [32] }\end{array}$ & Mouse & Collagen XVIII was stained in mouse islets \\
\hline IV & $\begin{array}{l}\text { Irving-Rodgers } \\
\text { (2014), [33] }\end{array}$ & Mouse & $\begin{array}{l}\text { Mouse islet basement membrane, comprising } \\
\text { collagen IV and other ECMs, including laminin, was } \\
\text { completely lost during islet isolation }\end{array}$ \\
\hline
\end{tabular}




\begin{tabular}{|c|c|c|c|}
\hline V & $\begin{array}{c}\text { Shima } \\
(2016),[26]\end{array}$ & Pig & $\begin{array}{l}\text { Collagen } \mathrm{V} \text { is a target for collagenase } \mathrm{G} \text {, whereas } \\
\text { collagens I and III are targets for collagenase } \mathrm{H} \\
\text { (porcine islet isolation) }\end{array}$ \\
\hline V, III, I & $\begin{array}{c}\text { Miyazaki } \\
\text { (2019), [34] }\end{array}$ & Rat & $\begin{array}{l}\text { Collagens III and } \mathrm{V} \text { were crucial for islet isolation, } \\
\text { and the population was different from the strains } \\
\text { of rat }\end{array}$ \\
\hline I, III & $\begin{array}{l}\text { Fujio } \\
(2014),[35]\end{array}$ & Rat & Collagenase $\mathrm{H}$ reacted to collagens I and III \\
\hline IV, V & $\begin{array}{l}\text { Vigier } \\
\text { (2017), [25] }\end{array}$ & $\begin{array}{l}\text { Mouse, } \\
\text { pig }\end{array}$ & $\begin{array}{l}\text { Collagens IV and V were stained peri- and intra- } \\
\text { islet in mouse }\end{array}$ \\
\hline I, III, V & $\begin{array}{l}\text { Van Deijnen } \\
\text { (1994), [24] }\end{array}$ & $\begin{array}{l}\text { Human, } \\
\text { pig, dog, } \\
\text { rat }\end{array}$ & $\begin{array}{l}\text { Collagen I was expressed in peri-islet and in the } \\
\text { lobar, lobular, and acinar septa weakly in pigs and } \\
\text { dogs and moderately in rats and humans } \\
\text { Collagen III is well developed on the lobar and } \\
\text { acinar septa in rats and dogs. The peri-islet displays } \\
\text { weakly in rats, dogs, and humans and very weakly } \\
\text { in pigs } \\
\text { Collagen V reacts moderately in rats, dogs, and } \\
\text { humans and weakly in pigs in the lobar and lobular } \\
\text { septa }\end{array}$ \\
\hline
\end{tabular}

It has been accepted that the distribution of pancreatic collagen in humans is similar to that in pigs. Hughes et al. revealed that collagens IV, V, and VI were distributed in the islet-exocrine interface and that the distribution of collagen I was widely observed. Particularly, peri-islet collagen VI was strongly expressed compared with collagens I and IV, as in pigs [28, 31]. They also certified that collagenase (Liberase HI; Roche Applied Science, Indianapolis, IN; Collagenase NB1 and neutral protease NB; Serva Electrophoresis, Heidelberg, Germany) digested collagen VI in not only exocrine tissues but also in peri- and intra-islets and caused damage to islets [19]. Furthermore, they showed that collagen IV was seen in the peri-islet basement membrane (peri-islet capsule) and was digested by collagenase [30]. It was digested more effectively using the blend of collagenase and neutral protease compared with single usage (collagenase or neutral protease) [29].

Regarding rodents, Irving-Rodgers et al. showed that collagen IV located in the peri- and intraislets was digested by the isolation process and recovered after engraftment in mice [33]. Vigier et al. also showed that collagens IV and V were seen around mouse islets [25]. Choong et al. revealed that collagen XVIII, as rare collagen, was strongly expressed in mouse islets [32]. Goto's group revealed that collagens I and III were located in the exocrine tissues of rat, especially collagen III, and that collagenase $\mathrm{H}$ (collagenase II) reacted to collagens I and III compared with collagenase $\mathrm{G}$ (collagenase I) [35]. Later, they revealed that the distribution between collagens I and III depends on the difference in rat strains [34].

In summary, there are some varieties in the distribution of the types of collagen among species. We consider that the understanding of the distribution is important to select suitable collagenase and acquire more islets with good qualities in islet isolation. 


\subsection{The Role of Collagen in Islet Transplantation: Supporter for the Improvement of the Endocrine Function of Islets}

Table 2 summarizes the important roles of collagen in islet transplantation regarding the improvement of the endocrine function of islets. Many studies have revealed that collagen, like laminin and fibronectin, contributed to the improvement of the viability of $\beta$ cells, prevented apoptosis of $\beta$ cells, and improved glucose-stimulated insulin secretion of $\beta$ cells with the expression of insulin-associated genes, especially in collagens I and IV [36-53].

Table 2 The roles of collagen in islet transplantation regarding the endocrine function.

\begin{tabular}{|c|c|c|c|}
\hline $\begin{array}{l}\text { Type of } \\
\text { collagen }\end{array}$ & $\begin{array}{c}\text { Author } \\
\text { (year), } \\
\text { Reference }\end{array}$ & $\begin{array}{l}\text { Role in islet } \\
\text { transplantation }\end{array}$ & Detailed results \\
\hline VI & $\begin{array}{c}\text { Wang } \\
\text { (2020), [36] }\end{array}$ & $\begin{array}{l}\text { Improved } \\
\text { viability, insulin- } \\
\text { releasing } \\
\text { function, and } \\
\text { reduced islet } \\
\text { immunogenicity }\end{array}$ & $\begin{array}{l}\text { Rat islets cultured with decellularized 3-D ECM } \\
\text { improved the survival, insulin content, and } \\
\text { glucose-stimulated insulin secretion } \\
\text { The ECM restored basement membrane- } \\
\text { related collagen VI associated with an } \\
\text { attenuation in islet immunogenicity }\end{array}$ \\
\hline IV & $\begin{array}{l}\text { Hadavi } \\
\text { (2019), [37] }\end{array}$ & $\begin{array}{l}\text { Improved } \\
\text { insulin-releasing } \\
\text { function }\end{array}$ & $\begin{array}{l}\text { Collagen IV and laminin scaffolds improved the } \\
\text { endocrine function of human islets }\end{array}$ \\
\hline IV & $\begin{array}{c}\text { Hadavi } \\
\text { (2018), [38] }\end{array}$ & $\begin{array}{l}\text { Improved } \\
\text { insulin-releasing } \\
\text { function }\end{array}$ & $\begin{array}{l}\text { Fibronectin and collagen IV improved insulin } \\
\text { secretion } \beta \text { cells }\end{array}$ \\
\hline III & $\begin{array}{l}\text { Olaniru } \\
\text { (2018), [39] }\end{array}$ & $\begin{array}{c}\text { Improved } \\
\text { viability and } \\
\text { insulin-releasing } \\
\text { function }\end{array}$ & $\begin{array}{l}\text { Collagen III prevented cytokine-induced } \\
\text { apoptosis and preserved insulin secretion } \\
\text { function in human islets }\end{array}$ \\
\hline 1 & $\begin{array}{l}\text { Stephens } \\
\text { (2018), [40] }\end{array}$ & $\begin{array}{c}\text { Improved } \\
\text { viability and } \\
\text { insulin-releasing } \\
\text { function }\end{array}$ & $\begin{array}{l}\text { Mouse islets encapsulated with collagen I } \\
\text { improved the viability and insulin secretion } \\
\text { Succeeded subcutaneous islet transplantation }\end{array}$ \\
\hline I, IV & $\begin{array}{l}\text { Nakashima } \\
\text { (2018), [54] }\end{array}$ & $\begin{array}{l}\text { Improved } \\
\text { adhesive ability }\end{array}$ & $\begin{array}{l}\text { The adhesive ability to fibronectin was better } \\
\text { than other ECMs for porcine exocrine tissues }\end{array}$ \\
\hline VI & $\begin{array}{l}\text { Llacua } \\
\text { (2018), [41] }\end{array}$ & $\begin{array}{c}\text { Improved } \\
\text { viability and } \\
\text { insulin-releasing } \\
\text { function }\end{array}$ & $\begin{array}{l}\text { Collagen VI improved the viability and insulin- } \\
\text { releasing function of encapsulated human } \\
\text { islets }\end{array}$ \\
\hline IV & $\begin{array}{l}\text { Llacua } \\
\text { (2018), [42] }\end{array}$ & $\begin{array}{l}\text { Improved islet } \\
\text { survival }\end{array}$ & $\begin{array}{l}\text { Survival including reductions of necrosis and } \\
\text { apoptosis of islets encapsulated with collagen } \\
\text { IV and laminin }\end{array}$ \\
\hline
\end{tabular}




\begin{tabular}{|c|c|c|c|}
\hline I & $\begin{array}{c}\text { Forget } \\
\text { (2017), [43] }\end{array}$ & $\begin{array}{l}\text { Improved islet } \\
\text { survival }\end{array}$ & $\begin{array}{l}\text { Improved cultured islet survival in the IGF- } 2 \\
\text { coated porous collagen microwells }\end{array}$ \\
\hline IV, I & $\begin{array}{l}\text { Llacua } \\
\text { (2016), [44] }\end{array}$ & $\begin{array}{l}\text { Improved } \\
\text { insulin-releasing } \\
\text { function }\end{array}$ & $\begin{array}{l}\text { Collagen IV improved the insulin-releasing } \\
\text { function of human islets, whereas there was } \\
\text { no effect in collagen I }\end{array}$ \\
\hline IV & $\begin{array}{l}\text { Liu } \\
\text { (2015), [45] }\end{array}$ & $\begin{array}{l}\text { Improved } \\
\text { viability and } \\
\text { insulin-releasing } \\
\text { function }\end{array}$ & $\begin{array}{l}\text { Collagen IV and fibronectin enhanced insulin } \\
\text { secretion and expression of } \beta \text { cell-associated } \\
\text { genes via the integrin/ focal adhesion } \\
\text { kinase/extracellular signal-regulated kinase } \\
\text { pathway }\end{array}$ \\
\hline IV & $\begin{array}{c}\text { Yap } \\
(2013),[46]\end{array}$ & $\begin{array}{l}\text { Improved } \\
\text { viability and } \\
\text { insulin-releasing } \\
\text { function }\end{array}$ & $\begin{array}{l}\text { Collagen IV-modified scaffold promoted islet } \\
\text { cell viability that enhanced insulin secretion }\end{array}$ \\
\hline IV & $\begin{array}{l}\text { Beenken- } \\
\text { Rothkopf } \\
\text { (2013), [47] }\end{array}$ & $\begin{array}{l}\text { Improved } \\
\text { insulin-releasing } \\
\text { function }\end{array}$ & $\begin{array}{l}\text { Encapsulated } \beta \text { cell line improved the insulin- } \\
\text { releasing function under the presence of } \\
\text { collagen IV, fibronectin, or laminin }\end{array}$ \\
\hline IV & $\begin{array}{c}\text { Gibly } \\
\text { (2013), [48] }\end{array}$ & $\begin{array}{l}\text { Improved } \\
\text { viability and } \\
\text { insulin-releasing } \\
\text { function }\end{array}$ & $\begin{array}{l}\text { Scaffolds using collagen IV supported } \\
\text { extrahepatic human islet transplantation with } \\
\text { the improvement of the engraftment and } \\
\text { function }\end{array}$ \\
\hline IV, I & $\begin{array}{c}\text { Sojoodi } \\
(2013),[55]\end{array}$ & N/A & $\begin{array}{l}\text { Laminin, but not collagens I, IV, or fibronectin, } \\
\text { induced comparable expression of the Ins1 } \\
\text { and Ins } 2 \text { genes in rat adult } \beta \text { cells }\end{array}$ \\
\hline IV & $\begin{array}{l}\text { Davis } \\
\text { (2012), [56] }\end{array}$ & $\begin{array}{l}\text { Improved } \\
\text { insulin-releasing } \\
\text { function }\end{array}$ & $\begin{array}{l}\text { Collagen IV and/or laminin-encapsulated } \\
\text { mouse islets with mesenchymal stem cells } \\
\text { improved the insulin-releasing function and } \\
\text { expression of insulin-associated genes }\end{array}$ \\
\hline I & $\begin{array}{c}\text { Jalili } \\
\text { (2011), [50] }\end{array}$ & $\begin{array}{l}\text { Improved } \\
\text { viability and } \\
\text { insulin-releasing } \\
\text { function }\end{array}$ & $\begin{array}{l}\text { A scaffold comprising collagen I and fibroblasts } \\
\text { improved the survival and insulin-releasing } \\
\text { function of mouse islets and improved the } \\
\text { long-term of islet isograft function }\end{array}$ \\
\hline IV & $\begin{array}{c}\text { Salvay } \\
\text { (2008), [51] }\end{array}$ & $\begin{array}{l}\text { Improved } \\
\text { insulin-releasing } \\
\text { function }\end{array}$ & $\begin{array}{l}\text { Mice transplanted islets onto scaffolds with } \\
\text { collagen IV achieved euglycemia fastest }\end{array}$ \\
\hline IV & $\begin{array}{c}\text { Kaido } \\
\text { (2006), [57] }\end{array}$ & N/A & $\begin{array}{l}\text { Collagen IV induced a decline of insulin mRNA } \\
\text { and a significant loss of insulin content in } \\
\text { human fetal } \beta \text { cells }\end{array}$ \\
\hline IV, I & $\begin{array}{c}\text { Pinkse } \\
\text { (2006), [52] }\end{array}$ & $\begin{array}{l}\text { Improved islet } \\
\text { survival }\end{array}$ & $\begin{array}{l}\text { Islets that had been cultured on collagen IV } \\
\text { showed better islet survival than collagen I }\end{array}$ \\
\hline I & $\begin{array}{c}\text { Edamura } \\
\text { (2003), [32] }\end{array}$ & N/A & $\begin{array}{l}\text { The insulin-releasing function of cultured } \\
\text { porcine islets was seen with laminin but not } \\
\text { with collagen I }\end{array}$ \\
\hline
\end{tabular}




\begin{tabular}{|c|c|c|}
\hline $\begin{array}{c}\text { Sakurai } \\
\text { (2003), [58] }\end{array}$ & $\begin{array}{l}\text { Promoted } \\
\text { angiogenesis }\end{array}$ & $\begin{array}{l}\text { Implantation of collagen I- or IV-coated foreign } \\
\text { body promoted neovascularization }\end{array}$ \\
\hline $\begin{array}{c}\text { Nagata } \\
\text { (2001), [53] }\end{array}$ & $\begin{array}{l}\text { Improved } \\
\text { viability and } \\
\text { insulin-releasing } \\
\text { function }\end{array}$ & $\begin{array}{l}\text { Insulin secretion of cultured islets with } \\
\text { collagen I or a mixture of collagen I and IV was } \\
\text { improved }\end{array}$ \\
\hline $\begin{array}{c}\text { Jiang } \\
\text { (1999), [59] }\end{array}$ & N/A & $\begin{array}{l}\text { Collagens I and IV inhibited } \beta \text { cell survival } \\
\text { Laminin contributed to the proliferation of } \beta \\
\text { cells }\end{array}$ \\
\hline
\end{tabular}

\section{N/A: not applicable}

Collagen IV is a major component of the peri- and intra-islet basement membrane [33]. The collagen works as a niche for transplanted islets and supports the improvement of insulin secretion $[37,46]$. For example, Yap et al. evaluated the condition of islets seeded into polymer scaffold with ECM, including collagen IV, laminin, and fibronectin, and elucidated that collagen IV improved the insulin-releasing function and viability of $\beta$ cells compared with other ECMs and shortened the time to normoglycemia in islet transplantation [46]. Salvay et al. also revealed that islet transplantation with collagen IV-coated scaffold was superior to other ECMs such as fibronectin and laminin in controlling the blood glucose level [51]. Furthermore, Beenken-Rothkopf et al. conducted a similar study using MIN6 $\beta$ cells embedded in polymer and showed that collagen IV improved the insulinreleasing function of the cells, the same as other ECMs such as laminin and fibronectin [47]. Other previous studies also revealed the contribution of collagen IV in greater insulin release of islets [44, $48,54,56,60]$, and the therapeutic effects were better than those of other ECMs [44]. Collagen IV also contributed to islet cell survival, prevention of apoptosis, and oxygen consumption rate of immunoisolating encapsulated islets $[41,42]$. Immunoisolating encapsulation is a technology that protects the containing islets in polymers, such as alginate, by preventing the infiltration of immunocompetent cells and antibodies.

Collagen I, which is also localized within and around islets such as collagen IV [24], promoted islet cellular survival and differentiation and also improved the $\beta$ cell function [61-63]. For example, Stephens et al. conducted the encapsulation of isolated mouse islets using collagen I oligomer and demonstrated the improvement of viability and insulin secretion of the encapsulated islets, as well as successful subcutaneous islet transplantation in both syngeneic and allogeneic models [40]. A similar trial was conducted by Jalili et al., who used a scaffold comprising collagen I and mouse fibroblasts to improve the survival and insulin-releasing function of mouse islets and improve the long-term islet isograft function [50]. Nagata et al. also reported similar results using rat islets [53]. Conversely, some groups have indicated that neither collagen I nor IV contributed to the improvement in endocrine function $[32,55,57,59]$.

These benefits of collagen in endocrine function are provided via the activation of the intracellular signaling pathway activated by ligation between collagen and integrin (Figure 1) [61]. Integrin is a transmembrane receptor that includes 24 different types and is known as an adhesion factor that combines various ECMs such as collagen, laminin, and RGD (Arg-Gly-Asp) motif [11]. Integrin is a heterodimer comprising two polypeptide chains known as $\alpha$ and $\beta$ subunits. There are $18 \alpha$ and $8 \beta$ subunits known [64]. Previous studies have revealed that integrin receptors for collagen 
in islets contained $\beta 1$ subunit ( $\alpha 1 \beta 1, \alpha 2 \beta 1, \alpha 3 \beta 1, \alpha v \beta 1, \alpha 10 \beta 1$, and $\alpha 11 \beta 1)$ [14, 57, 60, 65-69]. Integrin $\beta 1$ plays a pivotal role in the regulation of islet cell biology, survival, and function [70-72]. In other words, collagen contributes to the improvement of endocrine function via integrin $\beta 1$. For example, integrin $\alpha 3 \beta 1$ improves human $\beta$ cell survival [71] and insulin secretion of rat $\beta$ cell [72] by attaching ECMs. Integrin $\alpha v \beta 1$ promotes human $\beta$ cell adhesion [73], and integrin $\alpha 1 \beta 1$ also contributes to the adhesion, motility, and insulin secretion of human $\beta$ cell by binding to collagen IV [60]. Furthermore, collagen IV is localized to integrins $\alpha 3 \beta 1, \alpha 5 \beta 1$, and $\alpha 6 \beta 1$ during the development of the human fetal pancreas [67].

After binding collagen (especially collagen IV) and integrin $\beta 1$, the intracellular signaling pathways associated with focal adhesion kinase (FAK), which regulates cell proliferation, differentiation, and apoptosis, are activated (Figure 1). The activation of FAK promotes the two represented downstream signaling pathways: mitogen-activated protein kinase/extracellular signalregulated kinase (ERK) and phosphoinositide 3-kinase/Akt pathways. Liu et al. evaluated the endocrine function of rat $\beta$ cell line encapsulated with their developed conditioned peptide containing fibronectin and collagen IV motif and the mechanism. They revealed that fibronectinand collagen IV-encapsulated cells improved their insulin-releasing function, and the proliferation and expressions of $\beta$ cell-associated genes (Ins1, MafA, and $P d x-1)$ were enhanced in the cells. Furthermore, phosphorylated FAK and ERK were detected, but there was no enhancement of Akt protein in the encapsulated cells. The expression of integrin $\beta 1$ cyclin protein was also certified. They concluded that these improvements of endocrine function were caused by the activation of the FAK/ERK/cyclin signaling pathway via ligation between ECMs (including collagen) and integrin $\beta 1$ [45]. Other groups also showed similar results regarding the mechanism of improvement of endocrine function. Hammar et al. showed that the activation of the mitogen-activated protein kinase/ERK pathway by the activation of FAK via integrin $\beta 1$ improved the survival of rat isolated $\beta$ cells [74]. Saleem et al. demonstrated that the activation of FAK/ERK by integrin $\beta 1$ promoted differentiation and prolonged the survival of human fetal pancreatic islet cells [62]. Conversely, it was elucidated that the activation of the FAK/phosphoinositide 3-kinase/Akt pathway via interaction between collagen and integrin inhibited the cleavage of caspase 3 in the MIN6 $\beta$ cell line cultured with collagen IV [75] and promoted the proliferation of $\beta$ cells $[76,77]$.

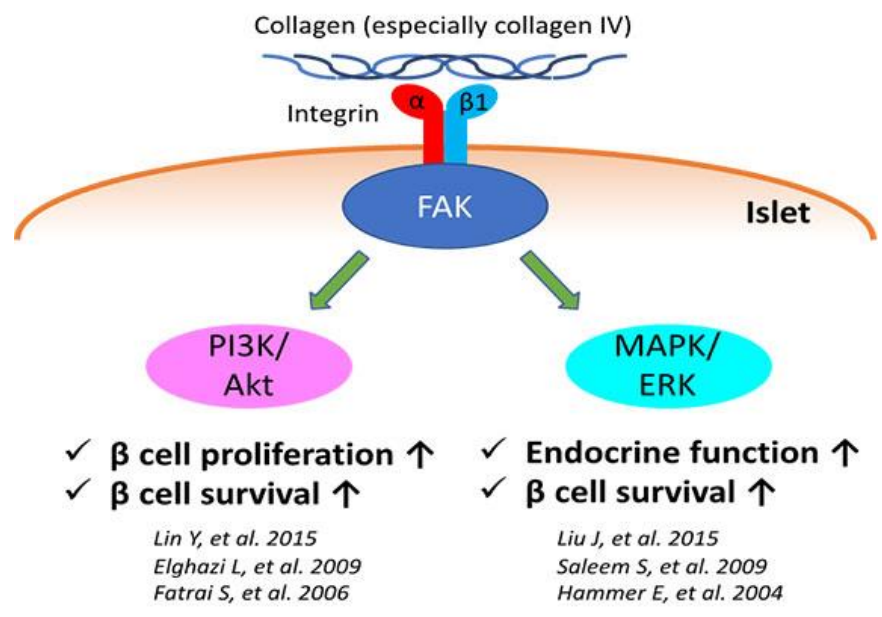

Figure 1 Interaction between collagen and integrin, and the resulting therapeutic effects. 


\subsection{New strategy for Improving Islet Transplantation Using Collagen}

Some research groups have attempted to show the possibility of collagen for the improvement of islet transplantation (Table 3). One strategy is to adopt a scaffold for developing new islet cells with additional values. Carvalho Oliverira et al. attempted to form swine islets with low immunogenicity by culturing single islet cells silenced by swine leucocyte antigen using collagen VI. Xenogeneic $T$ cell immune responses were significantly prevented in swine leucocyte antigensilenced islet cells, and the clusters constructed of the silenced cells harbored similar levels in the expression of the insulin gene and insulin-releasing function compared with control islets [78]. This strategy may contribute to the resolution of limited donor supplies by using xenogeneic islets with low immunogenicity. Yang et al. also attempted to form islet-like clusters from murine $\beta$ cell line by culturing in collagen IV-treated culture dish. They form 100-150 $\mu \mathrm{m}$-sized pseudoislets with high survival rate and good glucose-stimulated insulin secretion and revealed the improvement of the endocrine function of diabetic animals by transplantation [79]. Recently, Kogawa, Mochizuki, and colleagues showed that the encapsulation technique using human recombinant collagen I (Cellsaic) with mesenchymal stem cells contributed to the improvement of transplant efficacy of islet xenotransplantation by promoting angiogenesis [80, 81].

Another strategy is the adoption of a scaffold for differentiation into $\beta$ cells from pluripotent or somatic stem cells. This also aims to clear the problem of limited donor supplies by forming new islets. Regarding this strategy, collagens I and IV contribute to supporting the differentiation from mesenchymal stem cells [82] and pancreatic precursor cells [83, 84].

Collagen can also be used for making bioengineered islets. For example, Gibly et al. conducted the transplantation of human islets seeded into bioscaffold using collagen IV to diabetic immunodeficient mice and succeeded in achieving normoglycemia for more than four months [48]. Hiscox et al. certified the improvement of insulin-releasing function of subcutaneously transplanted islets covered by collagen gel with prevascular treatment [85]. Furthermore, it is believed that the combination of collagen with other biomaterials that have the ability of immune isolation and growth factors can be a valuable trial for the success of islet transplantation [61].

Table 3 Other possibilities of collagen.

\begin{tabular}{|c|c|c|c|}
\hline $\begin{array}{l}\text { Type of } \\
\text { collagen }\end{array}$ & $\begin{array}{c}\text { Author (year), } \\
\text { Reference }\end{array}$ & $\begin{array}{l}\text { Role of } \\
\text { collagen }\end{array}$ & Detailed results \\
\hline 1 & $\begin{array}{c}\text { Kogawa, } \\
\text { Mochizuki } \\
(2020),[80,81]\end{array}$ & $\begin{array}{l}\text { Material for } \\
\text { bioengineered } \\
\text { islets }\end{array}$ & $\begin{array}{l}\text { The encapsulation technique using human } \\
\text { recombinant collagen I (Cellsaic) with } \\
\text { mesenchymal stem cells contributed to the } \\
\text { improvement of transplant efficacy of islet } \\
\text { xenotransplantation (rat to mouse) by promotion } \\
\text { of angiogenesis. }\end{array}$ \\
\hline VI & $\begin{array}{l}\text { Carvalho } \\
\text { Oliverira } \\
\text { (2020), [78] }\end{array}$ & $\begin{array}{l}\text { Material for } \\
\text { the formation } \\
\text { of newly islets }\end{array}$ & $\begin{array}{l}\text { Porcine single islet cells silenced by swine } \\
\text { leucocyte antigen were cultured with collagen VI } \\
\text { Formed islets acquired low immunogenicity }\end{array}$ \\
\hline
\end{tabular}


IV Pokrywczynska (2015), [82]

IV

Yang (2013), [79]

I

Vernon (2012), [86]

Mason (2009), [83]

Cirulli

IV
Promoted $\beta$

cell differentiation

Material for the formation of newly islets

Material for bioengineered islets

\section{Promoted $\beta$} cell differentiation Development of endocrine progenitor cells
Collagen IV contributed to the differentiation of rat mesenchymal stem cells into islet-like cells

Formed pseudoislets from $\beta$ cell line with improved insulin-releasing function using collagen IV-treated culture dish

Used for bioengineered islets as a cushion aiming to prevent physical damage of the islets

Hydrogels containing collagen I promoted differentiation of a glucose-responsive $\beta$ cell population from dissociated precursor cells of rat Integrin $\alpha v \beta 3$ and $\alpha v \beta 5$ contributed to the development of human pancreatic endocrine cells by binding to collagen IV and fibronectin

\section{Conclusions}

We believe that the study on collagen will support the improvement of islet transplantation. For example, knowledge on the distribution of collagen in the pancreas is essential to select preferred collagenase, which digests pancreatic tissue without impairing islets, for islet isolation. This will lead not only to the increasing volume of acquired islets with good quality but also for designing suitable collagenase blends per pancreas for custom-made islet isolation. Furthermore, the benefit of collagen in improving the endocrine function of $\beta$ cells can be adopted for the development of bioengineering islets using collagen with good reactivity to glucose change, producing a suitable volume of insulin and resistance to apoptosis in transplantation. These innovations using collagen may provide a further evolution of this treatment.

\section{Acknowledgments}

We thank ENAGO (www.enago.jp) for English proofreading service.

\section{Author Contributions}

Naoaki Sakata planned the theme and described the first draft of this review. Gumpei Yoshimatsu revised the manuscript. Shohta Koadama revised the final version of this review.

\section{Funding}

This study was funded by a Grant-in-Aid for Scientific Research (C) (19K09839, NS) from the Ministry of Education, Culture, Sports, Science and Technology of Japan.

\section{Competing Interests}


The authors declare that no competing interests exist.

\section{References}

1. Shapiro AM, Lakey JR, Ryan EA, Korbutt GS, Toth E, Warnock GL, et al. Islet transplantation in seven patients with type 1 diabetes mellitus using a glucocorticoid-free immunosuppressive regimen. N Engl J Med. 2000; 343: 230-238.

2. Markmann JF, Rickels MR, Eggerman TL, Bridges ND, Lafontant DE, Qidwai J, et al. Phase 3 trial of human islet-after-kidney transplantation in type 1 diabetes. Am J Transplant. 2020. DOI: 10.1111/ajt.16174

3. Hering BJ, Clarke WR, Bridges ND, Eggerman TL, Alejandro R, Bellin MD, et al. Phase 3 trial of transplantation of human islets in type 1 diabetes complicated by severe hypoglycemia. Diabetes Care. 2016; 39: 1230-1240.

4. Monroy-Cuadros M, Salazar A, Yilmaz S, McLaughlin K. Bladder vs enteric drainage in simultaneous pancreas-kidney transplantation. Nephrol Dial Transplant. 2006; 21: 483-487.

5. Gruessner RW, Gruessner AC. The current state of pancreas transplantation. Nat Rev Endocrinol. 2013; 9: 555-562.

6. Vantyghem MC, Chetboun M, Gmyr V, Jannin A, Espiard S, Le Mapihan K, et al. Ten-year outcome of islet alone or islet after kidney transplantation in type 1 diabetes: A prospective parallel-arm cohort study. Diabetes Care. 2019; 42: 2042-2049.

7. Smink AM, Li S, Hertsig DT, de Haan BJ, Schwab L, van Apeldoorn AA, et al. The efficacy of a prevascularized, retrievable poly ( $D, L$, -lactide-co-epsilon-caprolactone) subcutaneous scaffold as transplantation site for pancreatic Islets. Transplantation. 2017; 101: e112-e119.

8. Sakata N, Hayes P, Tan A, Chan NK, Mace J, Peverini R, et al. MRI assessment of ischemic liver after intraportal islet transplantation. Transplantation. 2009; 87: 825-830.

9. Kourtzelis I, Kotlabova K, Lim JH, Mitroulis I, Ferreira A, Chen LS, et al. Developmental endothelial locus-1 modulates platelet-monocyte interactions and instant blood-mediated inflammatory reaction in islet transplantation. Thromb Haemost. 2016; 115: 781-788.

10. Piemonti L, Everly MJ, Maffi P, Scavini M, Poli F, Nano R, et al. Alloantibody and autoantibody monitoring predicts islet transplantation outcome in human type 1 diabetes. Diabetes. 2013; 62: 1656-1664.

11. Kuehn C, Vermette $P$, Fülöp T. Cross talk between the extracellular matrix and the immune system in the context of endocrine pancreatic islet transplantation. A review article. Pathol Biol. 2014; 62: 67-78.

12. Schaefer L, Schaefer RM. Proteoglycans: From structural compounds to signaling molecules. Cell Tissue Res. 2010; 339: 237-246.

13. Smink AM, de Vos $P$. Therapeutic strategies for modulating the extracellular matrix to improve pancreatic islet function and survival after transplantation. Curr Diab Rep. 2018; 18: 39.

14. Gordon MK, Hahn RA. Collagens. Cell Tissue Res. 2010; 339: 247-257.

15. Di Lullo GA, Sweeney SM, Korkko J, Ala-Kokko L, San Antonio JD. Mapping the ligand-binding sites and disease-associated mutations on the most abundant protein in the human, type I collagen. J Biol Chem. 2002; 277: 4223-4231.

16. Smith K, Rennie MJ. New approaches and recent results concerning human-tissue collagen synthesis. Curr Opin Clin Nutr Metab Care. 2007; 10: 582-590. 
17. Gelse K, Poschl E, Aigner T. Collagens-structure, function, and biosynthesis. Adv Drug Deliv Rev. 2003; 55: 1531-1546.

18. Bakilan F, Armagan O, Ozgen M, Tascioglu F, Bolluk O, Alatas O. Effects of native type II collagen treatment on Knee osteoarthritis: A randomized controlled trial. Eurasian J Med. 2016; 48: 95101.

19. Cross SE, Hughes SJ, Partridge CJ, Clark A, Gray DW, Johnson PR. Collagenase penetrates human pancreatic islets following standard intraductal administration. Transplantation. 2008; 86: 907911.

20. Balamurugan AN, Green ML, Breite AG, Loganathan G, Wilhelm JJ, Tweed B, et al. Identifying effective enzyme activity targets for recombinant class I and class II collagenase for successful human islet isolation. Transplant Direct. 2016; 2: e54.

21. Brandhorst $H$, Brandhorst $D$, Hesse $F$, Ambrosius D, Brendel M, Kawakami $Y$, et al. Successful human islet isolation utilizing recombinant collagenase. Diabetes. 2003; 52: 1143-1146.

22. Meyer T, Czub S, Chodnewska I, Beutner U, Hamelmann W, Klock G, et al. Expression pattern of extracellular matrix proteins in the pancreas of various domestic pig breeds, the Goettingen Minipig and the Wild Boar. Ann Transplant. 1997; 2: 17-26.

23. White SA, Hughes DP, Contractor $\mathrm{HH}$, London NJ. An investigation into the distribution of different collagen types within adult and juvenile porcine pancreata. J Mol Med. 1999; 77: 7982.

24. Van Deijnen JH, Van Suylichem PT, Wolters GH, Van Schilfgaarde R. Distribution of collagens type I, type III and type V in the pancreas of rat, dog, pig and man. Cell Tissue Res. 1994; 277: 115-121.

25. Vigier S, Gagnon H, Bourgade K, Klarskov K, Fulop T, Vermette P. Composition and organization of the pancreatic extracellular matrix by combined methods of immunohistochemistry, proteomics and scanning electron microscopy. Curr Res Transl Med. 2017; 65: 31-39.

26. Shima $H$, Inagaki A, Imura $T$, Yamagata $Y$, Watanabe $K$, Igarashi $K$, et al. Collagen $V$ is a potential substrate for clostridial collagenase $G$ in pancreatic islet isolation. J Diabetes Res. 2016; 2016: 4396756.

27. Meier RP, Meyer J, Muller YD, Szot GL, Bédat B, Andres A, et al. Pancreas collagen digestion during islet of Langerhans isolation. Transpl Int. 2020. DOI: $10.1111 /$ tri.13725

28. Spiers RM, Marzi J, Brauchle EM, Cross SE, Vaughan RH, Bateman PA, et al. Donor age significantly influences the Raman spectroscopic biomolecular fingerprint of human pancreatic extracellular matrix proteins following collagenase-based digestion. Acta Biomater. 2019; 99: 269-283.

29. Spiers RM, Cross SE, Brown HL, Bateman PA, Vaughan RH, Hughes SJ, et al. Development of a simple in vitro assay to assess digestion of the extracellular matrix of the human pancreas by collagenase enzyme blends. Cell Transplant. 2018; 27: 1039-1046.

30. Cross SE, Vaughan RH, Willcox AJ, McBride AJ, Abraham AA, Han B, et al. Key matrix proteins within the pancreatic islet basement membrane are differentially digested during human islet isolation. Am J Transplant. 2017; 17: 451-461.

31. Hughes SJ, Clark A, McShane P, Contractor HH, Gray DW, Johnson PR. Characterisation of collagen VI within the islet-exocrine interface of the human pancreas: Implications for clinical islet isolation? Transplantation. 2006; 81: 423-426. 
32. Edamura K, Nasu K, Iwami Y, Ogawa H, Sasaki N, Ohgawara H. Effect of adhesion or collagen molecules on cell attachment, insulin secretion, and glucose responsiveness in the cultured adult porcine endocrine pancreas: A preliminary study. Cell Transplant. 2003; 12: 439-446.

33. Irving-Rodgers HF, Choong FJ, Hummitzsch K, Parish CR, Rodgers RJ, Simeonovic CJ. Pancreatic islet basement membrane loss and remodeling after mouse islet isolation and transplantation: Impact for allograft rejection. Cell Transplant. 2014; 23: 59-72.

34. Miyazaki Y, Murayama K, Fathi I, Imura T, Yamagata Y, Watanabe K, et al. Strategy towards tailored donor tissue-specific pancreatic islet isolation. PLoS One. 2019; 14: e0216136.

35. Fujio A, Murayama K, Yamagata $Y$, Watanabe $K$, Imura T, Inagaki A, et al. Collagenase $H$ is crucial for isolation of rat pancreatic islets. Cell Transplant. 2014; 23: 1187-1198.

36. Wang H, Li S, Dai Q, Gonzalez A, Tran ON, Sun H, et al. Culture on a native bone marrow-derived extracellular matrix restores the pancreatic islet basement membrane, preserves islet function, and attenuates islet immunogenicity. FASEB J. 2020; 34: 8044-8056.

37. Hadavi E, Leijten J, Engelse $M$, de Koning E, Jonkheijm $P$, Karperien $M$, et al. Microwell scaffolds using collagen-IV and laminin-111 lead to improved insulin secretion of human islets. Tissue Eng Part C Methods. 2019; 25: 71-81.

38. Hadavi E, Leijten J, Brinkmann J, Jonkheijm $P$, Karperien $M$, van Apeldoorn A. Fibronectin and collagen IV microcontact printing improves insulin secretion by INS1E cells. Tissue Eng Part C Methods. 2018; 24: 628-636.

39. Olaniru OE, Pingitore A, Giera S, Piao X, Castanera Gonzalez R, Jones PM, et al. The adhesion receptor GPR56 is activated by extracellular matrix collagen III to improve beta-cell function. Cell Mol Life Sci. 2018; 75: 4007-4019.

40. Stephens $\mathrm{CH}$, Orr KS, Acton AJ, Tersey SA, Mirmira RG, Considine RV, et al. In situ type I oligomeric collagen macroencapsulation promotes islet longevity and function in vitro and in vivo. Am J Physiol Endocrinol Metab. 2018; 315: E650-E661.

41. Llacua LA, Hoek A, de Haan BJ, de Vos P. Collagen type VI interaction improves human islet survival in immunoisolating microcapsules for treatment of diabetes. Islets. 2018; 10: 60-68.

42. Llacua LA, de Haan BJ, de Vos P. Laminin and collagen IV inclusion in immunoisolating microcapsules reduces cytokine-mediated cell death in human pancreatic islets. J Tissue Eng Regen Med. 2018; 12: 460-467.

43. Forget A, Waibel M, Rojas-Canales DM, Chen S, Kawazoe N, Harding FJ, et al. IGF-2 coated porous collagen microwells for the culture of pancreatic islets. J Mater Chem B. 2017; 5: 220225.

44. Llacua A, de Haan BJ, Smink SA, de Vos P. Extracellular matrix components supporting human islet function in alginate-based immunoprotective microcapsules for treatment of diabetes. J Biomed Mater Res A. 2016; 104: 1788-1796.

45. Liu J, Liu S, Chen Y, Zhao X, Lu Y, Cheng J. Functionalized self-assembling peptide improves INS1 beta-cell function and proliferation via the integrin/FAK/ERK/cyclin pathway. Int J Nanomedicine. 2015; 10: 3519-3531.

46. Yap WT, Salvay DM, Silliman MA, Zhang X, Bannon ZG, Kaufman DB, et al. Collagen IV-modified scaffolds improve islet survival and function and reduce time to euglycemia. Tissue Eng Part $A$. 2013; 19: 2361-2372. 
47. Beenken-Rothkopf LN, Karfeld-Sulzer LS, Davis NE, Forster R, Barron AE, Fontaine MJ. The incorporation of extracellular matrix proteins in protein polymer hydrogels to improve encapsulated beta-cell function. Ann Clin Lab Sci. 2013; 43: 111-121.

48. Gibly RF, Zhang X, Lowe WL, Shea LD. Porous scaffolds support extrahepatic human islet transplantation, engraftment, and function in mice. Cell Transplant. 2013; 22: 811-819.

49. Davis NE, Beenken-Rothkopf LN, Mirsoian A, Kojic N, Kaplan DL, Barron AE, et al. Enhanced function of pancreatic islets co-encapsulated with ECM proteins and me senchymal stromal cells in a silk hydrogel. Biomaterials. 2012; 33: 6691-6697.

50. Jalili RB, Moeen Rezakhanlou A, Hosseini-Tabatabaei A, Ao Z, Warnock GL, Ghahary A. Fibroblast populated collagen matrix promotes islet survival and reduces the number of islets required for diabetes reversal. J Cell Physiol. 2011; 226: 1813-1819.

51. Salvay DM, Rives CB, Zhang $X$, Chen F, Kaufman DB, Lowe WL, et al. Extracellular matrix proteincoated scaffolds promote the reversal of diabetes after extrahepatic islet transplantation. Transplantation. 2008; 85: 1456-1464.

52. Pinkse GG, Bouwman WP, Jiawan-Lalai R, Terpstra OT, Bruijn JA, de Heer E. Integrin signaling via RGD peptides and anti-beta1 antibodies confers resistance to apoptosis in islets of Langerhans. Diabetes. 2006; 55: 312-317.

53. Nagata N, Gu Y, Hori H, Balamurugan AN, Touma M, Kawakami Y, et al. Evaluation of insulin secretion of isolated rat islets cultured in extracellular matrix. Cell Transplant. 2001; 10: 447451.

54. Nakashima Y, Miyagi-Shiohira C, Kobayashi N, Saitoh I, Watanabe M, Noguchi H. Adhesion characteristics of porcine pancreatic islets and exocrine tissue to coating materials. Islets. 2018; 10: e1460294.

55. Sojoodi M, Farrokhi A, Moradmand A, Baharvand $H$. Enhanced maintenance of rat islets of Langerhans on laminin-coated electrospun nanofibrillar matrix in vitro. Cell Biol Int. 2013; 37: 370-379.

56. Davis NE, Beenken-Rothkopf LN, Mirsoian A, Kojic N, Kaplan DL, Barron AE, et al. Enhanced function of pancreatic islets co-encapsulated with ECM proteins and mesenchymal stromal cells in a silk hydrogel. Biomaterials. 2012; 33: 6691-6697.

57. Kaido T, Yebra M, Cirulli V, Rhodes C, Diaferia G, Montgomery AM. Impact of defined matrix interactions on insulin production by cultured human beta-cells: Effect on insulin content, secretion, and gene transcription. Diabetes. 2006; 55: 2723-2729.

58. Sakurai T, Satake A, Nagata N, Gu Y, Hiura A, Doo-Hoon K, et al. The development of new immunoisolatory devices possessing the ability to induce neovascularization. Cell Transplant. 2003; 12: 527-535.

59. Jiang FX, Cram DS, DeAizpurua HJ, Harrison LC. Laminin-1 promotes differentiation of fetal mouse pancreatic beta-cells. Diabetes. 1999; 48: 722-730.

60. Kaido T, Yebra M, Cirulli V, Montgomery AM. Regulation of human beta-cell adhesion, motility, and insulin secretion by collagen IV and its receptor alpha1beta1. J Biol Chem. 2004; 279: 53762-53769.

61. Riopel M, Wang R. Collagen matrix support of pancreatic islet survival and function. Front Biosci. 2014; 19: 77-90. 
62. Saleem S, Li J, Yee SP, Fellows GF, Goodyer CG, Wang R. Beta1 integrin/FAK/ERK signalling pathway is essential for human fetal islet cell differentiation and survival. J Pathol. 2009; 219: 182-192.

63. Lucas-Clerc C, Massart C, Campion JP, Launois B, Nicol M. Long-term culture of human pancreatic islets in an extracellular matrix: Morphological and metabolic effects. Mol Cell Endocrinol. 1993; 94: 9-20.

64. Hynes RO. Integrins: Bidirectional, allosteric signaling machines. Cell. 2002; 110: 673-687.

65. Cheng JY, Raghunath M, Whitelock J, Poole-Warren L. Matrix components and scaffolds for sustained islet function. Tissue Eng Part B Rev. 2011; 17: 235-247.

66. Kuhn K, Eble J. The structural bases of integrin-ligand interactions. Trends Cell Biol. 1994; 4: 256-261.

67. Wang R, Li J, Lyte K, Yashpal NK, Fellows F, Goodyer CG. Role for beta1 integrin and its associated alpha3, alpha5, and alpha6 subunits in development of the human fetal pancreas. Diabetes. 2005; 54: 2080-2089.

68. Wang RN, Paraskevas S, Rosenberg L. Characterization of integrin expression in islets isolated from hamster, canine, porcine, and human pancreas. J Histochem Cytochem. 1999; 47: 499506.

69. Llacua LA, Faas MM, de Vos P. Extracellular matrix molecules and their potential contribution to the function of transplanted pancreatic islets. Diabetologia. 2018; 61: 1261-1272.

70. Kantengwa S, Baetens D, Sadoul K, Buck CA, Halban PA, Rouiller DG. Identification and characterization of alpha 3 beta 1 integrin on primary and transformed rat islet cells. Exp Cell Res. 1997; 237: 394-402.

71. Ris F, Hammar E, Bosco D, Pilloud C, Maedler K, Donath MY, et al. Impact of integrin-matrix matching and inhibition of apoptosis on the survival of purified human beta-cells in vitro. Diabetologia. 2002; 45: 841-850.

72. Bosco D, Meda P, Halban PA, Rouiller DG. Importance of cell-matrix interactions in rat islet betacell secretion in vitro: Role of alpha6beta1 integrin. Diabetes. 2000; 49: 233-243.

73. Kaido T, Perez B, Yebra M, Hill J, Cirulli V, Hayek A, et al. Alphav-integrin utilization in human beta-cell adhesion, spreading, and motility. J Biol Chem. 2004; 279: 17731-17737.

74. Hammar E, Parnaud G, Bosco D, Perriraz N, Maedler K, Donath M, et al. Extracellular matrix protects pancreatic beta-cells against apoptosis: Role of short- and long-term signaling pathways. Diabetes. 2004; 53: 2034-2041.

75. Lin Y, Sun Z. Antiaging gene klotho attenuates pancreatic beta-cell apoptosis in type 1 diabetes. Diabetes. 2015; 64: 4298-4311.

76. Fatrai S, Elghazi L, Balcazar N, Cras-Méneur C, Krits I, Kiyokawa H, et al. Akt induces beta-cell proliferation by regulating cyclin D1, cyclin D2, and p21 levels and cyclin-dependent kinase-4 activity. Diabetes. 2006; 55: 318-325.

77. Elghazi L, Bernal-Mizrachi E. Akt and PTEN: Beta-cell mass and pancreas plasticity. Trends Endocrinol Metab. 2009; 20: 243-251.

78. Carvalho Oliveira M, Valdivia E, Verboom M, Yuzefovych Y, Sake HJ, Pogozhykh O, et al. Generating low immunogenic pig pancreatic islet cell clusters for xenotransplantation. J Cell Mol Med. 2020; 24: 5070-5081. 
79. Yang KC, Wu CC, Yang SH, Chiu CC, Sumi S, Lee HS. Investigating the suspension culture on aggregation and function of mouse pancreatic beta-cells. J Biomed Mater Res A. 2013; 101: 2273-2282.

80. Kogawa R, Nakamura K, Mochizuki Y. A new islet transplantation method combining mesenchymal stem cells with recombinant peptide pieces, microencapsulated islets, and mesh bags. Biomedicines. 2020; 8: 299.

81. Mochizuki Y, Kogawa R, Takegami R, Nakamura K, Wakabayashi A, Ito T, et al. Comicroencapsulation of islets and MSC cellsaics, mosaic-like aggregates of MSCs and recombinant peptide pieces, and therapeutic effects of their subcutaneous transplantation on diabetes. Biomedicines. 2020; 8: 318.

82. Pokrywczynska M, Lewandowska MA, Krzyzanowska S, Jundzill A, Rasmus M, Warda K, et al. Transdifferentiation of bone marrow mesenchymal stem cells into the islet-like cells: The role of extracellular matrix proteins. Arch Immunol Ther Exp. 2015; 63: 377-384.

83. Mason MN, Arnold CA, Mahoney MJ. Entrapped collagen type 1 promotes differentiation of embryonic pancreatic precursor cells into glucose-responsive beta-cells when cultured in threedimensional PEG hydrogels. Tissue Eng Part A. 2009; 15: 3799-3808.

84. Cirulli V, Beattie GM, Klier G, Ellisman M, Ricordi C, Quaranta V, et al. Expression and function of alpha(v)beta(3) and alpha(v)beta(5) integrins in the developing pancreas: Roles in the adhesion and migration of putative endocrine progenitor cells. J Cell Biol. 2000; 150: 1445-1460.

85. Hiscox AM, Stone AL, Limesand S, Hoying JB, Williams SK. An islet-stabilizing implant constructed using a preformed vasculature. Tissue Eng Part A. 2008; 14: 433-440.

86. Vernon RB, Preisinger A, Gooden MD, D'Amico LA, Yue BB, Bollyky PL, et al. Reversal of diabetes in mice with a bioengineered islet implant incorporating a type I collagen hydrogel and sustained release of vascular endothelial growth factor. Cell Transplant. 2012; 21: 2099-2110.



Enjoy OBM Transplantation by:

1. Submitting a manuscript

2. Joining in volunteer reviewer bank

3. Joining Editorial Board

4. Guest editing a special issue

For more details, please visit:

http://www.lidsen.com/journals/transplantation 